\title{
Göç ve Kadın Sağlığı Hizmetleri
}

\author{
Migration and Women Health Services
}

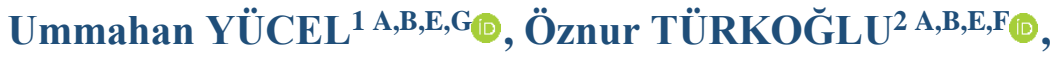

\author{
Aysun EKȘİOĞLU ${ }^{1}$ A,G \\ ${ }^{1}$ Ege Üniversitesi Sağlı Bilimleri Fakültesi, Ebelik Bölümü, İzmir, Türkiye \\ ${ }^{2}$ Ege Üniversitesi Sağlık Bilimleri Enstitüsü, İzmir, Türkiye
}

ÖZ

\begin{abstract}
Son yıllarda, insanlık tarihi kadar eski ve evrensel bir olgu olan göç bazı ülkelerde oldukça artmıştır. 2019 yılında tüm uluslararası göçmenlerin üçte biri sadece on ülkeden göç etmiştir. Suriye 8.2 milyon vatandaşının göç etmesi ile bu on ülke arasında birinci sıradadır. Türkiye, Suriye ile sınır komşuluğu nedeni ile son on yılda Suriye'den en fazla göç alan ülkedir. Ülkemiz, 2011 Suriye krizinden sonra, 3.6 milyon Suriye'den göçmene ev sahipliği yapmaktadır. Ülkemizde bulunan 1.651.627 göçmen kadının 820.495 'i üreme çağında Suriyeli kadın ve genç kızlardır. Göç olgusunda kadınlar, üreme sağlığ açısından hem göçmen hem de kadın olmanın çifte yükünü taşımaktadırlar. Bu derleme çalışmasında göçmen kadınların başlıca üreme sağlığı sorunlarından; gebelik, doğumla ilgili sorunlar (adölesan gebelik, sağlıksız düşük ve doğumlar, yüksek doğurganlık) ve üreme sağlığı hizmetlerine erişim engelleri literatür incelemesi ile ele alınmıştır.
\end{abstract}

Anahtar Kelimeler: Göç, kadın, üreme sağlığı, gebelik, doğum.

\section{ABSTRACT}

In recent years, migration which is a universal concept that is old as humanity has increased dramatically in several countries. In 2019, one third of the immigrants moved from only 10 countries. Syria comes first within those 10 countries since 8.2 million of its citizens have migrated. Turkey is the most immigrant-recieving country from Syria because they are border neighbors. Our country is hosting approximately 3.6 millions of Syrian immigrants after 2011 Syrian crisis. 820.495 of 1.651.627 Syrian women and young girls in our country are in their reproductive ages. In the concept of migration, women carry the double burden in terms of reproductive health;being both migrant and woman.In this compilation study, the problems of pregnancy and childbirth(adolescent pregnancy, unhealthy abortion and births, high fertility)and barriers of access to the reproductive health services are evaluated via literature.

Key Words: Migration, women, reproductive health, pregnancy, childbirth.

\section{GİRiş}

İnsanlık tarihi kadar eski ve evrensel bir olgu olan göç son yıllarda giderek artmaktadır (1). 2019 yllında tüm uluslararası göçmenlerin üçte biri sadece on ülkeden göç etmiştir. Suriye 8.2 milyon vatandaşının göç etmesi ile bu on ülke arasında ilk sıralardadır (2). Türkiye Suriye ile sınır komşuluğu nedeni ile son on yılda Suriye'den en fazla göç alan ülkedir (2). Türkiye, 2011 Suriye krizinden sonra, 3.6 milyon Suriyeli göçmene ev sahipliği yapmaktadır (3). Göçmenler beslenme, barınma sorunları yanı sıra önemli genel sağlık sorunları ile karşı karşıyadır. Dünya genelinde uluslararası tüm göçmenlerin \%47.9'unu oluşturan kadınlar ise 
tüm bu sorunların yanı sıra plansız gebelikler, gebelik, doğum ve doğum sonrası dönemde önemli üreme sağlığı sorunları ile karşı karşıya kalmaktadırlar (2).

Mülteciler Derneği’ne (2020) göre, ülkemizde 1.651 .627 göçmen kadın bulunmaktadır. $\mathrm{Bu}$ sayı, ülkemize göç eden toplam Suriyeli nüfusun \%46.1'ini oluşturmaktadır (4). Ülkemizdeki Suriyeli göçmenlerin 820.495 'i üreme çağında Suriyeli kadın ve genç kızlardır. On yaşın altındaki Suriyeli çocuk sayısı ise, 1 milyon 31 bin 226 kişi (\%28.7) dir (4). Türkiye'de doğan Suriyeli bebek sayısı ise 450 bin civarındadır (3). Türkiye Nüfus ve Sağlık Araştırması (TNSA 2018) verilerine göre, Türkiye'de Suriyeli göçmen bir kadın ortalama 5.3 çocuk doğurmaktadır (5).

Savaş ve çatışma sonrası zorunlu göç eden göçmenler sağlıklı olmayan koşullarda, toplu barınma yerlerinde, geleneksel yaşam sürdürmektedirler. Bununla birlikte, gelir düzeylerinin düşük olması nedeniyle beslenme yetersizlikleri, dil farklılığı, ırkçılık, ayrımcılık, sağlık sigortalarının olmamasına bağlı hizmet alamama, düşük toplumsal statü, sağlık çalışanı yetersizliği sağlı hizmet kullanımını ve sağlıklarını olumsuz etkilemektedir $(6,7,8)$. Kadınlar sadece göçmen olmanın değil, doğurganlık özelliklerinden dolayı iki kat fazla zorlukla karşılaşmaktadırlar (9). Bu nedenle göç olgusunda kadınlar ve çocuklar daha mağdur olup, sağlık açısından risk grubundadırlar $(9,10,11,12)$. Suriye savaşından kaçarak, ülkemize göç eden göçmenlerin en çok maruz kaldığı sağlık sorunları; acil tıbbi yardım, aile planlaması, gebelik bakımı ve doğum hizmetleri ile ilgilidir $(6,11,13,14)$.

Göçmen kadınların üreme sağlığına ilişkin başlıca sorunları, CYBE (Cinsel yolla bulaşan enfeksiyonlar), istismar, çocuk yaştaki erken evlilikler, adölesan gebelik, doğum öncesi, doğum ve doğum sonrası bakım almada problem, doğum komplikasyonları, düşük doğum ağırlıklı bebek, daha erken gebelik haftalarında doğum gibi sorunlardır $(6,9,13,14)$. Ülkemize gelen göçmenlerin aile planlaması hizmetlerinden yeterince yararlanamadıkları, istenmeyen gebelik yaşadıkları, gebelik kontrollerinin yeterince yapılmadığı, olumsuz doğum sonuçları ile karşı karşıya oldukları, maternal ve perinatal mortalite risklerinin daha fazla olduğu bildirilmektedir $(14,15,16)$. Ülkemize göç eden bireylerin çok sayıda çocuk sahibi olmaları, yüksek doğurganlık hızları ve aile planlaması hizmetlerinden az sayıda yararlanmaları, aile planlaması, doğum öncesi, doğum ve doğum sonu bakım hizmetlerinin önemini ortaya koymaktadır $(7,10)$.

\section{Aile Planlaması Hizmet Gereksinimi ve Hizmete Erişim}

Suriye, savaştan önce Arap Dünyasının en yükssek altıncı doğurganlık oranına sahip olduğu ülkedir. Savaş ve çatışma nedeniyle zorla yerinden edildikten sonra da Suriye halkı, doğurganlıklarını arttırmaya devam etmektedir (17).

Kadınların doğurganlık tercihini erken evlenme yaşı, eğitim düşüklüğü, çocuğa verilen anlam, kalabalık aile kültürüne verilen önem ve gebeliği önleyici yöntemlere ulaşamama gibi pek çok faktör etkilemektedir (7). Yapılan araştırmalar ilk evlenme yaşının düşük olduğu toplumların, ergen yaşlarda çocuk sahibi olma ve yüksek doğurganlıklarının olduğunu göstermektedir $(7,18,19,20)$. Suriyeli göçmen kadınların genç yaşta evlendikleri, doğurganlıklarının yüksek olduğu bilinmektedir. TNSA 2018 verilerine göre, 25-49 yaşlarındaki Suriyeli göçmen kadınların \%55'i 20 yaşına, \%38'i, 18 yaşına kadar ,\%12'si ise 15 yaşından önce evlenmektedir (5). Kıyak ve arkadaşları, Suriyeli göçmen kadınlar arasında 
adölesan gebeliklerin çoğunlukta olduğunu bildirmiştir (18). Kırşehir'e göç etmiş Suriyeli göçmen kadınlarla yapılan bir çalışmada, göçmen gebelerin \%13.2'sinin, Türk gebelerin ise \%4.1'inin adölesan olduğu bildirilmiştir (19). Bir başka çalışmada da, 12-19 yaş ergenlerin oranı Suriyeli gebelerde \%14.3, Türk gebelerde \%5.3'dür (20). Genç yaşta kız çocuklarını evlenmeye zorlayan ve doğum deneyimi yaşama ile yüz yüze bırakan koşullar çok yönlüdür. Tayland Myanmar sınırında 2016 yılında göçmen toplulukları ile yapılan nicel bir çalışmada, ergen gebeliğinin altında yatan temel nedenlerin yetersiz eğitim, üreme sağlığı konularında geleneksel görüş, evlilik öncesi istenmeyen cinsel ilişki, gebelik sonucu zorla evlendirilme, gebelik önleyici yöntemler hakkında bilgisizlik ve yöntemlere ulaşamama olduğu belirtilmiştir (21). Kadınların eğitim düzeylerinin düşüklüğü ile doğurganlık durumlarının ters orantıya sahip olduğu bilinmektedir (7). Türkiye'deki Suriyeli kadın göçmenlerin \%40'1 hiç eğitim almamış, \%13'ü ortaokul ve sadece \%37'si ilkokul mezunudur (5). Eğitimi olmayan veya ilkokulu bitirmemiş Suriyeli göçmen kadınların doğurganlık hızı 5.8 iken, lise veya üzeri eğitimi olan göçmen kadınlarda bu oran 4.1'dir (5).

Eğitim gibi bireysel faktörler dışında kültürel ve sosyal normlar doğurganlığı etkileyen önemli unsurlardandır. Lübnan'da Suriyeli göçmen kadınlarla yapılan bir çalışmada, Suriyeli kadınların savaş öncesinde de doğurganlığın kabul edilen bir sosyal norm olması nedeniyle, kadınların dört ile altı çocuk doğurmak istedikleri belirtilmiştir (17). Çok sayıda çocuk sahibi olmak özellikle de erkek çocuk isteği Suriye aileler de kültürcül ve toplumsal bir faktör olarak ortaya çıkmaktadır. Kadınlar kocalarının ikinci bir eşle evlenmemesi ve saygınlıklarını koruyabilmek için doğurma veya erkek çocuk doğurma baskısı yaşayabilmektedir (17). Karayaka ve arkadaşlarının ülkemizde yaşayan Suriyeli kadınlar ile yaptığı çalışmada, kadınlar Suriye'de bir evlilikte çocuğun olmaması durumunda çoğul evliliğin normal kabul edildiğini belirtmiştir. Aynı çalışmada doğurganlık sayısında eşlerinin, aile büyüklerinin, erkek çocuk isteğinin ve toplumun çocuk doğurma konusunda kadınlara yaptığı baskının önemli olduğu bildirilmiştir (7). Çocuk sayısının sosyal bir norm olması, büyük aile isteği, ailede en az bir erkeğin doğmasına verilen önem, aile isminin devamı, yaşlılık döneminde ebeveynlere ve kadın kardeşlerine destek sağlanması açısından çok sayıda çocuk ve erkek çocuk önemsenmektedir (17). Karakaya'nın çalışmasında, Suriyeli göçmenlerin doğurganlıklarının nedeni olarak, erkeğin soyunun devamı, toprağın işlenmesi, iş gücü, dini inanış ve mevcut savaş durumunda verdikleri kayıplar olduğu söylenmiştir (7). Somali'de yapılan bir çalışmada, dini inanç gereği çocuk sayısını sınırlamak amacıyla kontraseptif yöntem kullanmanın İslami değerlere aykırı olduğu belirtilmektedir (22). Yapılan çalışmalarda göçmen kadınların doğurganlıklarının fazla olduğu ve aile planlaması yöntemlerini daha az kullandıkları ortaya konulmuştur $(9,13,17)$. Lübnan'da 425 Suriyeli mülteci kadının dahil edildiği araştırmada, kadınların sadece \%34.5'inin gebeliği önleyici yöntem kullandıkları belirlenmiştir (17). Türkiye'deki Suriyeli kadınların kontraseptif yöntem kullanma oranı ise \%43'tür (5).

Suriyeli göçmenlerin kontraseptif yöntem kullanımını engelleyen durumlar sadece kültürel ve toplumsal normlar ile sınırlı değildir. Yöntemlerin maliyeti, bilgisizlik, sağlık hizmetlerine ulaşımda zorluk, dil problemleri, kontraseptif yöntemlere nasıl ulaşacaklarını bilmeme, eş desteği gibi hizmet sunumu ile ilgili faktörler ve hizmet kullanım engelleri de oldukça önemlidir $(7,9,12)$. Suriyeli kadınların doğurganlık ve aile planlaması için karar verme sürecinde erkek partnerin baskın bir rolü vardır $(17,23)$. Dikmen ve ark.'nın Türkiye'de yaşayan Suriyeli göçmen kadınların aile planlamasına karşı tutumlarını belirlemek amacı ile 
yaptıkları çalışmada kadınların eğitimi yanı sıra eşlerinin eğitim düzeyinin ve eşlerinin desteğinin aile planlamasına yönelik tutumlarını etkilediği saptanmıştır (17).

Bireysel, ailesel ve sosyokültürel faktörler dışında göçmen kadınların aile planlaması yöntem kullanımını etkileyen önemli bir bileşen de aile planlaması hizmetlerinin ulaşılabilir ve erişilebilir olmasıdır. Kontraseptif yöntemlere ücretsiz ulaşım yöntem kullanımını etkilemektedir (24). Lübnan'da yapılan bir çalışmada, Suriyeli göçmenler Rahim içi aracın yüksek maliyetinden endişe ettikleri vurgulanmaktadır. Bununla birlikte Suriye'de ulaşabildikleri enjekte edilebilir kontraseptiflere göç ettikleri ülkede ulaşamadıkları için takvim yöntemini kullanmayı tercih ettikleri aynı çalışmada öne çıkan bir bulgudur (17). Başka bir çalışmada ise Suriyeli göçmenlerin, Suriye'de sağlık ocaklarından ücretsiz temin ettikleri yöntemleri, Türkiye'de paralı olduğu için erişimde güçlük çektikleri bildirilmiştir (7). Morokko'da yapılan bir çalışmada oral kontraseptiflerin, İspanya'ya göç eden Faslı göçmenlerde ücretsiz olması nedeniyle en yaygın kullanılan doğum kontrol yöntemi olduğu belirtilmiştir (24). Göçmenler gelir düzeylerinin düşük olması nedeniyle en çok maliyeti düşük veya ücretsiz yöntemleri tercih etmekte, ücretli olan yöntemlere ulaşamadıklarında ise, geleneksel yöntemleri kullanmaktadırlar $(7,17)$. Ülkemizdeki Suriyeli göçmenler arasında \%18 ile geri çekme en sık kullanılan aile planlaması yöntemidir (5).

Aile planlaması hizmet kullanımını etkileyen faktörler, gebelik, doğum ve doğum sonu dönemlerde de sağlık hizmet kullanımına etkisini sürdürürken, bu dönemlere özgü yeni sorunların da eklenmesi ile anne-çocuk sağlığı sonuçları oldukça olumsuz etkilenmektedir. Özellikle istenmeyen veya planlı olmayan gebeliklerin takibi sağlıklı şekilde yapılamadığında sağlık sonuçları sadece gebe ve fetüsün sağlığı ile sınırlı kalmayıp, doğum ve doğum sonrası olumsuz anne ve bebek sağlığı sorunlarına da yol açmaktadır (9).

\section{Doğum Öncesi Bakım ve Doğum Hizmeti Kullanımı}

Suriyeli göçmenlerin \%96'sı kamp dışında yaşamakta ve sağlık hizmetine ulaşımda sıkıntı yaşamaktadır (25). Göç İdaresi Genel Müdürlüğü verilerine göre, Temmuz 2019 itibariyle, 8 ilde 11 göçmen kampında yaşayan göçmen sayısı 108.732, kamp dışında ise 3.514.016 kişidir (25). Kamplarda yemek, sağlık hizmeti, okul, temiz su, banyo, sosyal alanlar bulunurken, kamp dışında yaşayanlar yoksulluk nedeni ile zorlu yaşam koşulları yanı sıra sağlık hizmetlerine erişim sorunları ile karşı karşıyadır (26). AFAD (Afet ve Acil Durum Yönetimi Başkanlığı) kamp içinde kadınların sadece \%1.3'ü sağlık hizmetine ulaşamazken bu oranın kamp dışında \%53.5'e yükseldiğini bildirmiştir (27). Kamp dışında yaşayan kadınların sağlık hizmetinden faydalanmama nedenleri, hizmete ihtiyaç duymama, nereden hizmet alacağını bilmeme ve maddi zorluklardır (27). Diğer sağlık hizmetlerinde olduğu gibi kamp dışında yaşayan kadınlar doğum öncesi bakım (DÖB) ve doğum hizmetlerine erişimde sorunlar yaşamaktadır $(1,7,28,29,31)$. Göçmen kadınlar sağlık hizmetlerinden yararlanamadıklarında gebelik süreçleri zor geçmekte, riskli durumlar, evde doğumlar ve güvensiz düşükler görülebilmektedir $(7,29)$. Ülkemizde 2015-2018 yılları arasında gerçekleştirilen bir çalışmaya göre, Suriyeli göçmen gebelerin gebelik boyunca hastaneye hiç gitmeme oranı \%22 ile Türk gebelerden (\%3) yedi kat fazladır (1). Ülkemizde yapılan başka bir çalışmada, Suriyeli gebelerin DÖB almama oranı (\%41) Türk vatandaşı gebelere (\%7) göre altı kat fazladır (19). Benzer şekilde Hollanda'da yapılan bir çalışmada, ülke vatandaşları ile karşılaştırıldığında 
Afrika, Asya, Güney Amerika ve Türkiye kökenli göçmen kadınların DÖB'dan daha az faydalandıkları bildirilmiştir (30). DÖB sırasında kadının düzenli tartılması, kan basıncı takibi, tarama testleri ve kan tahlilleri yapılması sağlanmaktadır $(27,31)$. Türkiye'de üçüncü basamak sağlık kuruluşunda yapılan bir çalışmada göçmen gebelerin DÖB kapsamında yapılan ikili, üçlü tarama testlerinin, gestasyonel diyabet taramasının ve demir tedavisinin Türk gebelere göre daha düşük oranda yapıldığı görülmüştür (32). DÖB hizmetleri tıbbi muayene ve tarama testleri yanı sıra doğuma hazırlık açısından da oldukça önemlidir. DÖB almayan göçmen kadınlar doğum anında sağlık çalışanları ile daha fazla iletişim sorunu yaşamaktadırlar (33). Gebeliklerini sağlıksız geçiren ve yeterli beslenemeyen göçmen kadınlar, yaşadıkları yerdeki gebelere göre daha fazla kötü doğum sonuçlarıyla karşılaşmaktadırlar (29). Bunun yanı sıra sağlık hizmetine erişim sorunu pek çok olumsuz doğum sonucuna yol açmaktadır. DÖB almamış kadınların bu hizmeti alanlara göre doğumda maternal ölüm, perinatal ölüm riski olduğu bilinmektedir (7,26,31). Çift ve arkadaşlarının Bursa'da yaptığı çalışmada Suriyeli göçmen bebeklerin doğum kilolarının (3134.31 \pm 552.28$)$ Türkiyeli bebeklerden (3228.63 \pm 584.40$)$ daha düşük olduğu bulunmuştur (34). Güngör ve arkadaşlarının çalışmasında, doğumda Türk kadınlara göre Suriyeli kadınlarda gebelik haftası daha düşük bulunmuştur $(37.7 \pm 2.3$ 'e karş1 $36.4 \pm 2.3$ hafta, p <0.05) (15). Sawsan ve ark.(2018) çalışmasında, sosyoekonomik açıdan kötü durumda olan Suriyeli annelerde aynı yaş ve eğitimli Lübnanlı annelere göre prematür bebek doğurma oranı daha yüksek bulunmuştur (35). İtalya' da göçmenlerde erken doğum riskini araştıran bir çalışmada; Afrika'dan göç eden kadınların prematüre bebek doğurma oranı \%20.7, Asya ve Güney Amerikada'dan göç edenlerde \%13.6 ve İtalyan kadınlarda bu oran \%6.2'dir (36). İspanya'da perinatal mortalite kayıtları incelenerek yapılan bir araştırmada yerli kadınlar ile Doğu Avrupa ve Sahra altından göçen kadınların perinatal mortalite oranı karşılaştırılmış ve perinatal mortalite oranı İspanyol kadınlara göre daha yüksek bulunmuştur (37).

\section{Üreme Sağlığı Hizmet Kullanımındaki Engeller}

Göçmenlerin nüfusta kayıtsız olması hizmet kullanımında öncelikli sorundur (38). Suriyeli göçmenler 2015 yllında hizmet vermeye başlayan göçmen poliklinikleri ile bağışıklama ve aile planlaması hizmetleri almakta, ancak personel, fiziki donanım ve tıbbi malzeme eksikliği nedeniyle hizmet kullanımı kısıtlı şekilde sürdürülmektedir $(26,38,39)$. Nüfusa kaydı olmayan Suriyeliler, Aile Sağlığı Merkezlerindeki aile hekimliklerinde tıbbi kayıtlarının olmaması, sürekli yer değiştirmeleri ve Türkçe konuşamamaları nedeniyle hizmet alamamaktadır $(40,41)$.

Sağlık çalışanı yetersizliği, sağlık sisteminin işleyiş tarzının bilinmemesi, sunulan sağlık hizmetlerinin paralı olması, sağlık personelinin göçmenlerin yasal hakları ve özel ihtiyaçları ile ilgili yeterli düzeyde bilgiye sahip olamaması gibi durumlarda göçmenlerin sağl1k hizmetinden yararlanması zorlaşmaktadır (12). Alışkın olduğu toplumun dil ve kültüründen ayrılan ve farklı bir toplum ile yaşamaya başlayan göçmenler uyum güçlüğü yaşamakta, bulunduğu ülkenin resmi dilini konuşamadıkları için dil sorunu yaşamaktadırlar $(26,28)$. Göçmenlerin dil sorunu sosyal hayatlarını ve sağlık hizmeti alımını zorlaştırmaktadır (28). Sağlık hizmeti sırasında karşılıklı anlaşamama nedeniyle bakım ve hizmet uzun vakit almaktadır (39). Bursa' da yapılan bir çalışmada, göçmenlerin sadece hastalandıklarında sağlık kuruluşuna başvurdukları ve sağlık 
hizmetine başvurmama konusundaki en büyük engellerinin \%26.3 oranı ile dil engeli olduğu belirtilmiştir (42). Gönenç ve arkadaşlarının çalışmasında, göçmenlere sağlık hizmeti sunan ebelerin ve hemşirelerin \%97.3'ü bakımda yaşanılan en büyük sorunun dil sorunu olduğunu ifade etmişlerdir (43). Kanada'da yapılan benzer bir çalışmada, sağlık personelinin öncelikli engelinin dil engeli olduğu ifade edilmiştir (44). İrlanda 'da yapılan İrlandalı ebelerin göçmen kadınlara bakım sağlama deneyimlerini araştıran başka bir çalışmada, dil engeli ve kültürel farklılıkların bakım vermedeki zorluklarından bahsedilmektedir (45). Dil konusundaki sorun sadece göçmenleri değil sağlık çalışanlarını da etkilemektedir. Birinci basamakta çalışan aile hekimleri ve sağlık personeli iletişim konusunda yetersiz kaldıklarını ifade etmiştir (38). Göçmen hastalar ile aile hekimleri arasında yapılan bir çalışmada, doktorlar ve hastalar arasında dil farklılı̆̆ı olması nedeniyle anlaşamadıkları ve tercümanlara ihtiyaç duyduklarını ancak, tercümanın kendilerini ne kadar anlayıp, hastaya ne kadar yararlı olduğunu bilmediklerini belirtmişlerdir $(25,41)$.

Göçmenlerin yaşadığı engeller bireysel özelliklerin dışında hizmet sunanlardan da kaynaklanmaktadır (46). Göçmen kadınlar, bazı sağlık personelinin kendileriyle daha az ilgiledikleri ve kendilerine güler yüzlü davranmadıklarından yakınmaktadır (47). Lübnan'da göçmen kadınlarla yapılan bir çalışmada, sağlık personelinin kötü muamelede bulunması ve kendileriyle gülerek dalga geçilmesi nedeniyle aşağılanmalarının üzüntüsünü dile getirmişlerdir (16). Sağlık personelinin ilgisizliği, göçmenlere kültürel ayrımcılık uygulaması, aşağılaması, kötü davranış ve tutumda bulunmaları göçmen kadınları olumsuz etkilemektedir $(9,46) . \mathrm{Bu}$ durum nedeniyle üreme sağlığı hizmeti alırken eşitsizliklerle karşılaşacaklarını düşünmelerine ve sağlık personeline güvenmemelerine neden olmaktadır (7).

Suriyeli kadınlar, dini ve kültürel nedenlerden ötürü kadın sağlık personelinden hizmet almayı tercih etmektedir $(16,48)$. Lübnan'da Suriyeli kadınlarla yapılan bir çalışmada göçmen kadınlar, sağlık merkezlerindeki kadın hekimlerin eksikliğini dile getirerek, kadınsal sorunları için kadın jinekoloğa muayene olmak istediklerini, erkek doktora görünmenin inançlarında olmadığını belirtmişlerdir (16). Suriyeli göçmenlere bakım veren öğrencilerle yapılan bir çalışmada, göçmen kadınların erkek sağlık personelinden bakım almak ve onlarla konuşmak istemedikleri bildirilmiştir (48). Kanada'da göçmen gebe kadınlarla yapılan bir çalışmada, gebe göçmen kadınlar bakımlarında sadece kadın sağlık personeli istemektedirler (44). Şam'da yaşayan Suriyeli kadınlarla yapılan bir çalışmada, kadınların \%85'ten fazlası, doğumlarını kadın sağlık çalışanı ile yapmak istediğini söylemiştir (49).

\section{SONUÇ}

Göçmen kadınlar, zor yaşam koşulları yanı sıra önemli üreme sağlığı riskleri ve nitelikli üreme sağlığı hizmetlerine erişim sorunları yaşamaktadır. Göçmenler ana-çocuk sağlığı ve aile planlaması hizmetlerinden yeterince yararlanamamakta, istenmeyen gebelikler ve kötü doğum sonuçları ile karşı karşıya kalabilmektedir. Göçmen kadınların doğum öncesi bakım alma, hastanede doğum yapma, doğum sonu bakım alma oranları düşük, gebelik ve doğum komplikasyonları yüksektir. Bireysel, sosyoekonomik ve kültürel faktörlerin yanı sıra sağlık hizmet sunumu ve sağlık çalışanlarının olumsuz tutumlarından kaynaklı bazı faktörler nitelikli üreme sağlığı hizmet kullanımlarını kısıtlayabilmektedir. Göçmen kadınlara yönelik üreme sağlığı hizmetleri evrensel ilkeler dikkate alınarak, ayrımcılık yapılmadan hizmete ulaşım ve 
süreklilik sağlanarak güçlendirilmelidir. Sağlık hizmet sunumu göçmen kadınların üreme sağlığı hizmetine erişimini kolaylaştırıcı ve kültürlerine duyarlı olacak şekilde güçlendirilmeli, tercüman hizmetleri gibi kolaylaştırıcı yöntemler ile desteklenmelidir. Aynı zamanda sağlık çalışanlarının ihtiyaç duyduğu konularda hizmet içi eğitimler düzenlenerek, transkültürel bakış açısı kazanmaları sağlanmalı ve göçmen sağlığına özel bir yaklaşım ile bakım vermeleri teşvik edilmelidir.

\section{Çıkar Çatışması}

$\mathrm{Bu}$ çalışmada yazarların çıkar çatışması durumları yoktur.

\section{KAYNAKLAR}

1. Şirin, B., Ersoy, S., Pala, E. (2019). Suriyeli Geçici Sığınmacılar ve Türkiye Cumhuriyeti Vatandaşlarının Gebelik ve Doğum Sonuçlarının Karşılaştırılması: 3. Basamak bir Hastanede Yapılmış Vaka Kontrol Çalışması. Smyrna Tıp Dergisi, 25-32. https://www.smyrnatipdergisi.com/dosyalar_upload/belgeler/Suriyeli\%20gebeler1569 918886.pdf (Erişim Tarihi: 9 Nisan 2020)

2. United Nations, Department of Economic and Social Affairs, Population Division. https://www.un.org/en/development/desa/population/index.asp (Erişim Tarihi: 01.04.2020)

3. UNHCR, BM Mülteci Örgütü. https://www.unhcr.org/tr/turkiyedeki-multeciler-vesiginmacilar (Erişim Tarihi: 01.04.2020)

4. Mülteciler Derneği. https://multeciler.org.tr/turkiyedeki-suriyeli-sayisi/ (Erişim Tarihi: 01.04.2020)

5. Türkiye Nüfus ve Sağlık Araştırması Suriyeli Göçmen Örneklemi (TNSA )2018. http://www.hips.hacettepe.edu.tr/tnsa2018/rapor/2018_TNSA_SR.pdf (Erişim Tarihi: 01.04.2020)

6. Süt, H. K. (2017). Suriye'den göç eden kadınlar ve üreme sağlığı sorunları. Sağllk ve Toplum, 27(1), 3-7.

7. Karakaya, E., Coşkun, A. M, Özerdoğan, N., Yakıt, E. (2017). Suriyeli mülteci kadınların doğurganlık özellikleri ve etkileyen faktörler: kalitatif bir çalışma. Uluslararası Sosyal Araştırmalar Dergisi, 10(48), 417-428.

8. Aksu, H. \& Sevil, Ü. (2010). Göç ve kadın sağlığı. Maltepe Üniversitesi Hemşirelik Bilim ve Sanatı Dergisi, 2(3), 133-138.

9. Yağmur, Y. \& Aytekin, S. (2018). Mülteci kadınların üreme sağlı̆̆ı sorunları ve çözüm önerileri. Dokuz Eylül Üniversitesi Hemşirelik Fakültesi Elektronik Dergisi, 11 (1), 5660.

10. Kara, P. \& Nazik, E. (2018). Göçün kadın ve çocuk sağlı̆̆ına etkisi. Gümüşhane Üniversitesi Sağllk Bilimleri Dergisi, 7(2), 58 -69.

11. Kurtuldu, K. \& Şahin, E. (2018). Göçün kadın yaşamı ve sağlı̆̆ üzerine etkileri. Ordu Üniversitesi Hemşirelik Çalışmaları Dergisi, 1(1), 37-46.

12. Filiz, M. \& Yıldırım, T. (2019). Türkiye ve Avrupa Birliği ülkelerinde göçmenlere yönelik sağlık politikalarının değerlendirilmesi. Türk Akademik Sosyal Bilimler Araştırma Dergisi, 2(1), 24-30.

13. Demirci, H., Topak, N. Y Ocakoglu, G., Gömleksiz, M. E, Üstünyurt, E., Türker, A. Ü. (2017). Birth characteristics of Syrian refugees and Turkish citizens in Turkey in 2015. International Journal of Gynecology \& Obstetrics, 137(1), 63-66. doi: 10.1002/ijgo.12088. 
14. Dikmen, H. A., Cankaya, S., Yilmaz, S. D. (2019). The attitudes of refugee women in Turkey towards family planning. Public Health Nursing, 36(1), 45-52. doi: 10.1111/phn.12553. Epub 2018 Sep 27.

15. Aydoğan, S. \& Metintaş, S. (2017). Türkiye'ye gelen dış göç ve sağlığa etkileri. Türk Dünyası Uygulama Ve Araştırma Merkezi Halk Să̆lı̆̆ Dergisi, 2(2), 37-45. http://openaccess.ogu.edu.tr:8080/xmlui/bitstream/handle/11684/1391/31-222PB.pdf? sequence $=1 \&$ isAllowed $=y$ (Erişim Tarihi: 03.04.2020)

16. Güngör, E. S., Seval, O., İlhan, G., Verit, F.F. (2018). Do Syrian refugees have increased risk for worser pregnancy outcomes? Results of a tertiary center in Istanbul. Turkish journal of obstetrics and gynecology, 15(1), 23-27. doi: 10.4274/tjod.64022

17. Khasholian, T. K., Mourtada R., Bashour H., Kak, F. E., Zurayk H. (2017). Perspectives of displaced Syrian women and service providers on fertility behaviour and available services in West Bekaa, Lebanon. Reprod Health Matters, 25(1), 75-86. doi: 10.1080/09688080.2017.1378532.

18. Kiyak, H., Gezer, S., Ozdemir, C., Gunkaya, S., Karacan, T., Gedikbasi, A., (2020). Comparison of deivery characteristics and early obsstetric outcomes between Trukish women and Syrian refugee pregnancies. Nigerian Journal of Clinical Practice, 23(1), 12-17. doi: 10.4103/njcp.njcp_10_18.

19. Cantürk, F. K. \& Cantürk, M. (2019). Kırşehir ilindeki Suriyeli mültecilerin perinatal sonuçlarının değerlendirilmesi. Ahi Evran Tip Dergisi, 3(1), 6-11.

20. Erenel, H., Mathyk, B. A, Sal, V., Ayhan, I., Karataş, S., Bebek, A. K. (2017). Clinical characteristics and pregnancy outcomes of syrian refugees:a case-control study in a tertiary care hospital in İstanbul. Kemer Jinekoloji Obstetric, 295(1), 45-50. https://link.springer.com/article/10.1007\%2Fs00404-016-4188-5. (Erişim Tarihi: 03.04.2020)

21. Asnong, C., Fellmeth, G., Plugge, E., Wai, NS., Pimanpanarak, M., Paw, MK., et al.. (2018). Adolescents' perceptions and experiences of pregnancy in refugee and migrant communities on the Thailand-Myanmar border: a qualitative study. Reproductive Health, 15(83), 1-13. doi: 10.1186/s12978-018-0522-7.

22. Gele, A. A, Musse, F. K, Qureshi, S. (2019). Unmet needs for contraception: A comparative study among Somali immigrant women in Oslo and their original population in Mogadishu, Somalia. PLoS ONE, 14(8), 1-12. doi: 10.1371/journal.pone.0220783. eCollection 2019

23. Gümüş, Y. ve Bilgili, N. (2015). Göçün sağlı üzerine etkileri. Anadolu Hemşirelik ve Sağllk Bilimleri Dergisi, 18(1), 63-67.

24. Alvarez-Nieto C., Pastor-Moreno G., Grande-Gascón M., Linares-Abad M. (2015). Sexual and reproductive health beliefs and practices of female immigrants in Spain: a qualitative study. Reproductive Health. 12:79 DOI 10.1186/s12978-015-0071-2

25. T.C. İç İşleri Bakanlığı Göç İdaresi Müdürlüğü https://www.goc.gov.tr/gecicikorumamiz-altindaki-suriyeliler (Erişim Tarihi:01.04.2020)

26. Savaş Göç ve Sağlı, 2016 Türk Tabipleri Birliği Yayınları, Ankara https://ttb.org.tr/kutuphane/siginmacilar_rpr.pdf (Erişim Tarihi:19.05.2020)

27. T.C. İç İşleri Bakanlığı Afet ve Acil Durum Başkanlığı (AFAD) 2017. Türkiye'deki Suriyelilerin Demografik Görünümü, Yaşam Koşulları ve Gelecek Beklentilerine Yönelik Saha Araştırması, Ankara, Türkiye. https://www.afad.gov.tr/suriye-raporlari.( Erişim Tarihi:01.05.2020).

28. İnsan Hakları ve Mazlumlar için Dayanışma Derneği (Mazlumder) Kamp Dışında $\begin{array}{lllll}\text { Yaşayan Kadın } & \text { Siğınmacılar } & \text { Raporu. } & \text { Mayıs } & 2014\end{array}$ https://www.mazlumder.org/tr/main/yayinlar/yurt-ici-raporlar/3/mazlumder-kampdisinda-yasayan-suriyeli-kadin/1151 (Erişim Tarihi:01.05.2020) 
29. Öztürk, A. (2017). Göçlerin kadın sağlığına etkileri. Turkiye Klinikleri J Public HealthSpecial Topics, 3(1), 41-8.

30. Redshaw M. (2015). Dutch midwives perceive a mixture of rewards and difficulties when caring for non-western women. Evidence-Based Nursing, 18(1), 24. DOI: 10.1136/eb-2014-101736

31. Pirinçci, E., Polat, A., Köroğlu A., Kumru, S. (2010). Bir üniversite hastanesinde doğum yapan kadınların doğum öncesi bakım alma durumu ve etkileyen faktörler. ADÜ Tip Fakültesi Dergisi, 11(2), 1-7.

32. Ozel, S., Yaman, S., Kansu-Çelik, H, Hancerliogulları, N., Balci, N., Engin-Ustun, Y. (2018). Obstetric outcomes among Syrian refugees: A comparative study at a tertiary care maternity hospital in Turkey. Rev Bras Ginecol Obstet, 40(11), 673-679. DOI: 10.1055/s-0038-1673427

33. Boerleider, A. W, Francke, A. L., Mannien, J., Wiegers, T. A., Deville, W. L. (2013). A mixture of positive and negative feelings.A qualitative study of primary care midwives with non westwrn clients living. International journal of nursing studies, 50(12), 1658-1666. doi: 10.1016/j.ijnurstu.2013.04.009.

34. Çift, T., Temur, M., Korkmazer, E., Sayg1, A. İ., Ballı, Ö., Üstünyurt, E. (2017). Türkiye ve Suriyeli göçmen kadınlara ait gebelik ve seroloji sonuçlarının karşılaştırılması. Smrna Tip Dergisi, 5(9), 26-32.

35. Abdulrahim, S., El Rafei, R., Beydoun, Z., El Hayek, GY., Nakad, P.,Yunis, K. (2019).A test of the epidemiological paradox in a context of forced migration: low birthweight among Syrian newborns in Lebanon. International Journal of Epidemiology, 48(1), 275-286. doi: 10.1093/ije/dyy200.

36. Sosta E, Tomasoni LR, Frusca T, Triglia M, Pirali F, El Hamad I.(2008). Preterm Delivery Risk in Migrants in Italy: An Observational Prospective Study. Journal of Travel Medicine, 15(4):243-47. DOI: 10.1111/j.1708-8305.2008.00215.x

37. Rio Sanchez I., Bosch Sanchez S., Castello Pastor A., Lopez-Masida A., Garcia Senchermes C., Zurriaga L. O. et al. (2009) Perinatal mortality assessment in native and immigrant women: influence of exhaustiveness and quality of the registries. Gac Sanit, 23:403-409 DOI: 10.1016/j.gaceta.2009.01.007

38. Cenkci, Z. \& Nazik, E. (2018). Sığınmacı ve mülteci kadınların yaşadığı sorunlar ve sunulan sağlık hizmetleri. Anadolu Hemşirelik ve Sağllk Bilimleri Dergisi, 21(4), 293 299.

39. Göçmen Sağlığı Merkezleri Halk Sağlığı Genel Müdürlüğü https://hsgm.saglik.gov.tr/tr/göçmen-sağlı̆̆ 1 -merkezleri.html (Erişim Tarihi: 01.05.2020).

40. Yardan, E. D., Us, N. C., \& Yardan T. (2016). Göçmen hastalarla aile hekimliği personeli arasındaki iletişim. Samsun Sağlık Bilimleri Dergisi, 1(2), 83-92.

41. Aygün, O., Gökdemir, Ö. Bulut, Ü., Yaprak, S., (2016). Güldal, D., Bir Toplum Sağlı̆̆1 Merkezi Örneğinde Sı ̆̆ınmacı ve Mültecilere Verilen Birinci Basamak Sağlık Hizmetlerinin Değerlendirilmesi. TJFM\&PC;10(1):6-12. DOI: 10.5455/tjfmpc.199143

42. Duysak, T. (2017). Suriyeli mülteciler krizi ve uluslararası örgütlerin Türkiye'deki destek faaliyetleri sağlık sorunu. Yüksek Lisans Bitirme Projesi. Galatasaray Üniversitesi Sosyal Bilimler Enstitüsü, İstanbul.

43. Gönenç, İ. M., Göktaş, M., Dursun, R. A., Çökelek, F., Ercan, N., Şahin, D. (2018). Opinions and cultural sensitivities of midwives and nurses about providing health care to women seeking asylum. Journal of Human Sciences, 15(2), 683-696.

44. Winn, A., Hetherington, E., Tough, S. (2018). Caring for pregnant refugee women in a turbulent policy landscape: perspectives of health care professionals in Calgary, Alberta. Int J Equity Health, 17(91), 1-14. doi: 10.1186/s12939-018-0801-5. 
45. Tobin, C. L. \& Murphy-Lawless J. (2014). Irish midwives' experiences of providing maternity care to non-Irish women seeking asylum. International Journal of Women's Health, 31(6), 159-169. doi: 10.2147/IJWH.S45579.

46. Beşer, A. \& Kerman, K. T. (2017). Göç eden bireylerin öncelikli sağlık sorunları ve sağlık hizmetine ulaşımdaki engeller. Türkiye Klinikleri J. Public Health Nurse Special Topics, 3(3), 143-148.

47. Önal, A. \& Keklik, B. (2016). Mülteci ve sığınmacıların sağlık hizmetlerine erişimde yaşadığı sorunlar: Isparta ilinde bir uygulama. Süleyman Demirel Üniversitesi Vizyoner Dergisi, 7 (15), 132-148.

48. Yıldırım, J. G. (2019). Mültecilere bakım veren hemşire öğrencilerin deneyimleri:Olgubilim çalışması. Sted dergisi, 28(4), 263-271.

49. Bashour, H. and Abdulsalam, A. (2005). Syrian women's preferences for birth attendant and birth place. Birth Issues in Perinatal care, 32(1), 20-26. doi: 10.1111/j.07307659.2005.00333.x.. 